\title{
DAMPAK PENGGUNAAN SMARTPHONE TERHADAP PENDIDIKAN KARAKTER ANAK DI ERA MILENIAL
}

\section{Dana Aswadi dan Heppy Lismayanti}

\author{
STKIP PGRI Banjarmasin \\ Jalan Sultan Adam, Komplek H. Iyus, No. 18 RT.23 Banjarmasin, \\ Kalimantan Selatan. Kode pos 70121 \\ email: dadan899@yahoo.co.id, heppylismayanti@ stkipbjm.ac.id
}

\begin{abstract}
ABSTRAK
Zaman milenial sekarang ini, anak sudah bisa menggunakan berbagai media yang tersedia, khususnya bisa menggunakan HP cerdas yang dinamakan juga dengan smartphone. Banyak aplikasi yang terdapat dalam HP mengindikasikan salah satu gambaran sebuah perubahan dalam suatu zaman, yaitu hadirnya zaman milenial. Zaman ini berarti anak kecil sudah bisa dan mampu menggunakan HP dalam kesehariannya. orang tua memiliki peran terhadap pembentukan karakter anak dengan penggunaan smartphone sekarang ini. Pembentukan karakter sayogiyanya menjadi salah satu dasar pendidikan yang diberikan kepada anak

Metode yang digunakan adalah metode deskriptif, yaitu memberikan gambaran yang jelas berkenaan dengan peran orang tua terhadap pembentukan karakter anak dengan penggunaan smartpone. Teknik pengumpulan data yang digunakan berupa; a) teknik simak, b) teknik catat, dan c) teknik rekam.

Hasil penelitian ini menemukan, a) karakter positif, berupa memiliki pengetahuan, kreatifitas tinggi, sabar, jujur, dan ceria. dan b) karakter negatif, berupa egois, sombong, labil, dan penyendiri.

Kata kunci : pendidikan karakter, smartphone, milenial

\section{PENDAHULUAN}

Zaman milenial sekarang ini, anak sudah bisa menggunakan berbagai media yang tersedia, khususnya bisa menggunakan HP cerdas yang dinamakan juga dengan smartphone. HP ini berisi berbagai aplikasi baik secara online maupun ofline yang bisa memiliki dampak positif bahkan juga dampak negatif tergantung siapa yang menggunakannya dan aplikasi apa yang digunakannya. Seorang anak bisa saja kecanduan terhadap aplikasi yang ada pada HP tersebut apalagi aplikasinya bukan berisi konten yang mendidik secara positif malah beirisi konten yang mendidik secara negatif, misalnya permainan perang. Permainan ini mengandung unsur kekerasan dan selalu memberikan gambaran bahwa kemenangan lebih baik dari kekalahan. Oleh karena itu, anak pun menjadi orang yang keras, selalu ingin menang dan tidak mau mengalah terhadap siapapun. Ada juga, sebuah aplikasi dengan konten yang memberikan pendidikan, misalnya saja permainan memasak. Permainan mengandung satu hal yang positif, yaitu bagaimana anak belajar caranya
\end{abstract}


memasak sehingga memunculkan keinginan dia untuk bisa memasak dan mengikuti sesuai dengan permainan tersebut. Ini adalah salah satu gambaran bahwa HP yang dinamakan smartphone sekarang ini menjadi salah satu yang bisa menjadi positif atau negatif tergantung dari penggunaannya.

Banyak aplikasi yang terdapat dalam HP mengindikasikan salah satu gambaran sebuah perubahan dalam suatu zaman, yaitu hadirnya zaman milenial. Zaman ini berarti anak kecil sudah bisa dan mampu menggunakan HP dalam kesehariannya. Hal ini tentunya tidak lepas dari peran orang tua yang juga ikut menjadi andil dalam pembentukan anak. Orang tua menjadi kontroler terhadap setiap kegiatan anak. Oleh karena itu, ketika anak diberikan HP oleh orang tuanya maka ada dua hal yang akan didapatkan anaknya, apakah anak ini akan memiliki dampak negatif atau positif. Artinya, anak yang bisa menggunakan HP ini juga akan terbentuk berupa sikap sikap yang akhirnya akan merubah kepribadian anak, yaitu berupa karakter anak.

Apabila kita sinkronisasikan antara orang tua, anak, serta pembiaran atau penstrukturan penggunaan HP pada anak maka akan memunculkan sebuah dampak kemudian hari, yaitu dampak pada kepribadian anak. Kepribadian anak ini memunculkan sebuah karakter yang terbentuk melalui smartphone. Oleh karena itu, orang tua berarti memiliki peran terhadap pembentukan karakter anak dengan penggunaan smartphone sekarang ini. Pembentukan karakter sayogiyanya menjadi salah satu dasar pendidikan yang diberikan kepada anak.

\section{METODE}

Metode yang digunakan adalah metode deskriptif, yaitu memberikan gambaran yang jelas berkenaan dengan peran orang tua terhadap pembentukan karakter anak dengan penggunaan smartpone.

Teknik pengumpulan data yang digunakan seperti diuraikan Arikunto (1998:100) menyebutkan bahwa metode pengumpulan data adalah cara-cara yang digunakan peneliti untuk mengumpulkan data. Adapun teknik yang digunakan dalam pengumpulan informasi berupa; a) teknik simak, yaitu berupa penyimakan terhadap berbagai informasi atau data yang dikumpulkan dari naraseumber, b) teknik catat, yaitu berupa catatan yang dilakukan dengan pencatatan hal hal yang penting yang berkenaan dengan informasi atau data sesuai dengan peran orang tua terhadap pembentukan karakter anak dengan menggunakan smartphone, dan c) teknik rekam, yaitu berupa teknik perekaman, baik terpimpin maupun bebas sesuai dengan pedoman yang dibuat. 


\section{HASIL DAN PEMBAHASAN}

\section{Pembentukan Karakter pada Anak}

Ryan mengungkapkan berkenaan dengan karakter yang disampaikan oleh Sudrajat (2011: 48) bahwa kata character berasal dari bahasa Yunani charassein, yang berarti to engrave (melukis, menggambar), seperti orang yang melukis kertas, memahat batu atau metal. Berakar dari pengertian yang seperti itu, character kemudian diartikan sebagai tanda atau ciri yang khusus, dan karenanya melahirkan sutu pandangan bahwa karakter adalah 'pola perilaku yang bersifat individual, keadaan moral seseorang'. Setelah melewati tahap anak-anak, seseorang memiliki karakter, cara yang dapat diramalkan bahwa karakter seseorang berkaitan dengan perilaku yang ada di sekitar dirinya. Hal ini senada dengan yang disampaikan oleh Fajarini (2014: 128), yaitu karakter merupakan standarstandar batin yang terimplementasi dalam berbagai bentuk kualitas diri. Karakter diri dilandasi nilai-nilai serta cara berpikir berlandaskan nilai-nilai tersebut dan terwujud dalam perilaku. Indonesia Heritage Foundation merumuskan beberapa bentuk karakter yang harus ada dalam setiap individu bangsa Indonesia, di antaranya adalah: cinta kepada Allah dan alam semesta beserta isinya, tanggung jawab, disiplin, mandiri, jujur, hor mat dan santun, kasih sayang, peduli dan kerja sama, percaya diri, kreatif, kerja keras dan pantang menyerah, keadilan dan kepemimpinan, baik dan rendah hati, toleransi, cinta damai dan persatuan.

Istilah karakter diambil dari bahasa Yunani yang berarti 'to mark' (menandai), istilah ini lebih fokus pada tindakan atau tingkah laku. Wynne menjelaskan adanya dua pengertian tentang karakter. Pertama, menunjukkan bagaimana seseorang bertingkah laku. Apabila seseorang berperilaku tidak jujur, kejam dan rakus, tentulah orang tersebut memanifestasikan perilaku buruk. Sebaliknya, apabila seseorang berperilaku jujur, suka menolong, tentulah orang tersebut memanifestasikan karakter mulia. Kedua, istilah karakter erat kaitannya dengan "personality". Seseorang baru bisa disebut 'orang yang berkarakter' (a person of character) apabila tingkah lakunya sesuai kaidah moral. (Fajarini, 2014: 128-129)

Karakter adalah watak, tabiat, akhlak, atau kepribadian seseorang yang terbentuk dari hasil internalisasi berbagai kebajikan (virtues) yang diyakini dan digunakan sebagai landasan untuk cara pandang, berpikir, bersikap, dan bertindak (Kementerian Pendidikan Nasional, 2010: 3). Sudrajat (2011: 48) menyebutkan bahwa Karakter yang baik berkaitan dengan mengetahui yang baik (knowing the good), mencintai yang baik (loving the good), dan melakukan yang baik (acting the good). 
Arif (2017: 138) menyebutkan bahwa istilah karakter secara harfiah berasal dari bahasa Latin "Charakter", yang antara lain berarti: watak, tabiat, sifat-sifat kejiwaan, budi pekerti, kepribadian atau akhlak. Sedangkan secara istilah, karakter diartikan sebagai sifat manusia pada umumnya dimana manusia mempunyai banyak sifat yang tergantung dari faktor kehidupannya sendiri. Karakter adalah sifat kejiwaan, akhlak atau budi pekerti yang menjadi ciri khas seseorang atau sekelompok orang. Definisi dari "The stamp of individually or group impressed by nature, education or habit. Karakter merupakan nilai-nilai perilaku manusia yang berhubungan dengan Tuhan Yang Maha Esa, diri sendiri, sesama manusia, lingkungan, dan kebangsaan yang terwujud dalam pikiran, sikap, perasaan, perkataan, dan perbuatan berdasarkan norma-norma agama, hukum, tata krama, budaya, dan adat istiadat.

Karakter anak di rumah terbentuk dikarenakan peran dari orang tua. Orang tua secara tradisional menggunakan kata-kata atau bahasanya dalam membentuk karakter. Bahkan, bisa juga menggunakan sikap serta tindakan dalam membuat karakter anak. Di zaman milenial ini, semua berubah. Anak sejak dini sudah mengenal smartphone atau HP. Bahkan, mereka sudah bisa menggunakannya tanpa belajar formal, artinya secara otodidak mereka sudah mengetahuinya. Oleh karena itu, ketika mengamati fenomena ini, ada beberapa karakter anak yang bisa dibuat oleh orang tua sebagai perannya dalam sebuah pembentukan karakter. Adapun karakter yang terbentuk dari smartphone ini ada karakter positif dan karakter negatif.

\section{Dampak Positif pada Karakter Anak}

Karakter positif yang terbentuk dari penggunaan smartphone di era milenial ini tergambar dengan sebuah.

a. Pengetahuan

Bagi anak yang sering menggunakan aplikasi yang berkenaan dengan pendidikan selalu memberikan kepada anak berupa pengetahuan. Pendidikan selalu mengutamakan kognitif, apektif, fan psikomotorik. Dengan aplikasi yang ada, maka sudah mencakup diantaranya kognitifnya. Anak yang awalnya tidak mengetahui, maka dengan mengunduh aplikasi yang sifatnya mendidik, maka anakpun bisa mendapatkan pengetahuan yang lebih dibanding anak yang lainnya. Misalnya, aplikasi berupa permainan berupa tebak huruf, tebak angka, dan yang lainnya. Permainan itu bukan hanya memberikan tebakan berupa angka, huruf, maupun yang lainnya. Akan tetapi, ia juga memberikan informasi kepada anak berkenaan dengan hal tersebut. Oleh sebab itu, anak yang awalnya tidak mengetahui huruf atau angka maka dengan 
adanya permainan tersebut maka ia pun mengetahuinya. Hal ini menunjukkan bahwa aplikasi tersebut memiliki sebuah hal yang positif yang bisa membangun pengetahuan anak.

Bukan hanya aplikasi berupa permainan, tetapi aplikasi lainnya juga berupa pengetahuan. Misalnya saja, google, google map, WA, Facebook. Semua aplikasi itu bisa memberikan pengetahuan kepada anak. Sekarang, dicontohkan saja aplikasi google. Google itu merupakan aplikasi yang bisa digunakan untuk mencari berbagai ilmu pengetahuan yang ada, baik di lokal, nasional, bahkan juga bisa pengetahuan secara Internasional. Artinya, anak bisa saj menggunakan aplikasi google tersebut untuk mencari berbagai ilmu pengetahuan. Misalnya saja, anak mencari berkenaan dengan ilmu biologi. Ia mencari tumbuhan obat. Anak bisa menemukannya dengan mudah di aplikasi tersebut. Begitu juga yang lainnya, seperti google map. Google map bisa memberi pengetahuan bagi anak tentang jalan atau arah tujuan yang ingin/ akan ditujunya. Bahkan, WA sebagai sosial media pun sebenarnya juga bisa memberikan pengetahuan kepada anak. Hal ini bisa saja tergambar dari berbagai informasi yang dibagikan melalui WA. Dari berbagai uraian ini, maka sangat jelas sekali bahwa smartphone bisa digunakan secara positif untuk bisa memperoleh pengetahuan tergantung dari peran orang tua mengarahkan penggunaannya.

\section{b. Kreatifitas tinggi}

Anak yang sering memegang smartphone pasti akan berbeda dengan anak yang jarang atau tidak pernah memegangnya. Sebuah hal yang membuat perbedaannya secara positif adalah memunculkan kreatifitas yang tinggi pada anak. Anak memiliki kreatifitas terhadap berbagai hal tergantung dari aplikasi apa yang digunakannya. Misalnya saja, sebuah aplikasi permainan masak. Dalam permainan itu terdapat sebuah kegiatan membuat makanan. Dari memilih bahan, alat memasaknya, bahkan sampai dengan memasaknya. Hal ini memunculkan sebuah kreatifitas anak karena anak diminta sekreatif mungkin untuk membuat sebuah makanan yang diambil dari benda yang sesuai dengan keinginannya sehingga terbentuk sebuah makanan yang enak. Permainan ini mengarah pada psikomotorik anak, yaitu sebuah permainan yang mengehendaki terciptanya sebuah keterampilan anak. Ketika diaplikasikan di dunia nyata, ia sudah mengetahui benda apa saja yang disiapkan untuk memasak. Bahkan, pencampuran bahan yang dimasak pun sudah diketahuinya secara dini. Hal ini menandakan bahwa kreatifitasnya sudah mulai terbentuk dari aplikasi yang dimainkannya. Bukan hanya aplikasi permainan memasak, tetapi kreatifitas ini juga terbentuk dari berbagai aplikasi lainnya seperti FB, 
Instagram, maupun yang lainnya. Anak secara bebas membuat kreatifitas berupa tulisan di dalam beranda FB. Misalnya, ia mencoba sebuah tulisan sastra, yaitu puisi. Kemudian, ia tuliskan di beranda dan disebarkannya. Ini bisa menjadi sebuah kreatifitas bagi dia di bidang karya sastra. Bahkan, ketika ada yang mengkritik tentang tulisannya, maka ia pun bisa secara kreatif memberikan tanggapan terhadap kritikan orang lain tersebut. Pastinya, tidak mudah membangun kreatifitas dalam menulis dikarenakan kekurangpercayaan terhadap diri barangkali tulisannya tidak diterima oleh orang lain, tetapi hal ini ternyata menjadi sesuatu hal yang berbeda ketika dilakukan di FB, bahkan seakan hal ini menjadi suatu hal yang mudah.

c. Sabar

Karakter selanjutnya yang terbentuk dari penggunaan smartphone adalah karakter sabar. Sabar adalah sebuah sikap yang baik, tidak pernah menanggapai sesuatu dengan emosi atau terburuburu. Ketika dihadapkan pada suatu permasalahan maka ia akan memikirkannya serta mencari jalan keluarnya dengan berhati-hati. Hal ini menunjukkan kesabarannya. Dalam penggunaan aplikasi di smartphone pun bisa menjadikan anak menjadi anak yang memiliki sikap sabar. Anak ini bisa menjadi seorang yang memiliki karakter sabar tergantung dari aplikasi yang digunakannya. Misalnya saja, aplikasi yang berisi konten agama. Dalam aplikasi itu terdapat nasehat yang mengindikasikan agar anak menjadi sabar. Dengan konten agama itu, anak dapat mengetahui sikap sabar itu seperti apa sehingga bisa mengaplikasikannya ke kehidupan. Bukan hanya itu, dalam aplikasi permainan pun kadang juga ada yang mengarahkan anak agar bisa menjadi seorang yang penyabar, misalnya permainan memancing. Permainan ini sebagaimana memancing di dunia nyata juga memberikan sebuah kesabaran bagi pemainnya, baik dari pemilihan umpan sampai dengan memancingnya. Memancing pada aplikasi ini memerlukan kesabaran menunggu sampai akhirnya di makan ikannya. Ketika di makan ikan, ia pun harus berjuang agar bisa mendapatkan ikannya bahkan terkadang talinya putus atau ikannnya terlepas dari kailnya. Permainan ini mengajarkan kepada anak agar bisa sabar menerima apapun keputusan dari suatu hal walaupun sudah direncanakan dengan matang. Akan tetapi, terkadang, sesuatu tidak sesuai dengan perencanaannya. Ternyata, sebuah karakter sabar ini bisa muncul sesuai dengan aplikasi apa saja yang memang mengandung sebuah pendidikan berupa sikap yang positif kepada anak sehingga anak pun menjadi orang yang sabar. Artinya, tetap diperlukan peran orang tua untuk mengawasi aplikasi apa saja yang digunakan di smartphone. 


\section{d. Jujur}

Kejujuran merupakan kunci dari etos kehidupan. Dengan kejujuran, orang memiliki sebuah karakter yang baik sehingga bisa mendapat kepercayaan dari orang lain dari berbagai urusan. Jujur ini menjadi salah satu karakter yang bisa terbentuk melalui smartphone. Asalkan orang tua sebagai orang yang berada di lingkungan keluarga memberikan sebuah arahan kepada anak serta memberikan nasehat kepadanya pentingnya kejujuran. Jadi, anak harus jujur ketika menggunakan smartphone.

e. Ceria

Anak diharapkan mendapatkan sebuah kebahagiaan dengan aplikasi yang tersedia di smartphone. Dengan kebahagiaan yang didapatkan anak, maka dapat memudahkannya dalam menerima berbagai ilmu pengetahuan. Bahkan, kebahagiaan juga bisa memunculkan daya kreativitas, berupa keterampilan di bidang kreatif.

\section{Dampak Negatif pada Karakter Anak}

Selain karakter positif, smartphone juga memberikan dampak negatif apabila tidak digunakan dengan baik. Bahkan, apabila tidak ada bimbingan dari orang tua maka akan menciptakan karakter negatif anak. Adapun karakter negatif yang bisa muncul akibat penggunaan smartphone sebagai berikut.

a. Egois

Dalam karakter manusia, sering muncul sebuah sikap yang mementingkan diri sendiri. Hal ini dikarenakan adanya sebuah karakter yang dipengaruhi oleh penggunaan smartphone secara negatif. Dengan sikap egois ini, anak akan bertindak sesuatu hal yang menurut dia benar tanpa memperhatikan berbagai kondisi serta saran dari orang lain. Ia lebih mengutamakan pendapat serta pemikirannya dibandingkan dengan pendapat orang lain.

b. Sombong

Ketika anak sering bermain aplikasi permainan yang ada di smartphone maka akan memunculkan sikap sombong. Apalagi dalam permainan tersebut, ia selalu menang. Kemenangan yang didapatkan ketika bermain permainan tersebut memunculkan sikap sombong karena merasa diri paling hebat dan selalu menang. 
c. Labil

Sikap labil sering menghampiri orang yang suka bermain media sosial. Apapun yang berkenaan dirinya selalu ingin diekspos. Apalagi dengan adanya HP sekarang ini, orang akan lebih mudah mengeksposnya. Kadang, apa yang diekspos ini sering berubah dikarenakan pola pikirannya yang terpengaruh oleh keadaan atau apa yang tertulis di media sosial. Ketika ada sesuatu yang dirasakan dalam kehidupan atau ada yang dibacanya di media sosial yang menyenangkan maka dia akan mengekspresikan diri dengan cara menulis ekspresinya dalam sebuah status di media sosial.

d. Pesimis

Sikap pesimis. Dalam hal ini, anak lebih mudah menyerah dalam kehidupan. Hal ini dikarenakan kesehariannya yang selalu mementingkan penggunaan smartphone, baik untuk bermain permainan maupun bermedia sosial. Karena kebiasaan ini, maka ketika dihadapkan sebuah permasalahan di dunia nyata maka ia pun akan mudah menyerah dan sebagai pelariannya adalah main permainan atau media sosial.

e. Penyendiri

Anak yang sering main HP terkadanga memiliki dunianya sendiri. Anak akan mengindahkan atau meniadakan dunia yang lainnya. Bahkan anak tidak memperhatikan lagi siapapun dan apapun disekitarnya. Hal ini disebabkan konsentrasinya terfokus pada HP. Anak yang tidak menghiraukan disekitarnya ini akan menikmati kehidupan sendiri sehingga hal ini pun akan menciptakan suatu jurang pemisah antara dirinya dengan lingkungan sekitar. Hal tersebut akan menjadikan anak menjadi sulit bergaul dan beradabtasi dengan keadaan sekitar sehingga menjadikannya menjadi anak yang penyendiri.

Dampak positif maupun negatif yang diperoleh oleh anak saat menggunakan smartphone dikarenakan bimbingan para orang tua dan lingkungannya. Oleh karena itu perlu kiranya sebuah aturan khusus agar anak bisa memperoleh dampak positif yang mampu memberikan motivasi atau keoptimisan kepada anak bukan dampak negatif yang malah akan menjadikan suatu hal yang dapat merugikan anak ke depannya.

Dengan smartphone, bisa diajarkan kepada anak karakter yang baik maupun yang tidak baik. Dengan mengetahui dampak positif dan dampak negatif penggunaan smartphone maka akan diketahui karakter apa yang bisa tercipta melalui penggunaan smartphone ini. Karakter yang baik dengan dampak yang baik atau karakter negatif dengan dampak yang negatif. 


\section{SIMPULAN}

Berdasarkan uraian di atas maka disimpulkan bahwa.

1. Karakter anak bisa tercipta dari penggunaan smartphone, baik karakter yang memiliki dampak positif atau karakter yang memiliki dampak negatif.

2. Dampak positif yang bisa tercipta dari penggunaan smartphone diantaranya; pengetahuan, kreatifitas tinggi, sabar, jujur, dan ceria.

3. Dampak negatif yang bisa tercipta dari penggunaan smartphone diantaranya; egois, sombong, labil, dan penyendiri.

4. Perlu peran orang tua dan lingkungan anak untuk bisa menciptakan karakter anak yang positif.

\section{SARAN}

Ada beberapa saran kepada berbagai pihak berkenaan dengan dampak penggunaan smartphone terhadap anak, yaitu.

1. Orang tua, sayogiyanya memberikan pengawasan kepada anak secara intensif masalah penggunaan smartphone agar digunakan secara bijak dan positif.

2. Masyarakat, memberikan edukasi berkenaan dampak apa saja yang akan terjadi apabila anak terlalu sering menggunakan smartphone.

3. Sekolah/ intansi, memberikan aturan berkenaan dengan penggunaan smartphone agar anak tidak diperbolehkan membawa atau menggunakannya tanpa pengawasan dari pihak sekolah/ intansi atau dari pihak lainnya.

\section{DAFTAR RUJUKAN}

Arif, Rifda Mardian. 2017. Implementasi Pendidikan Karakter dalam Pembelajaran Sains. Stilistika: Jurnal Bahasa, Sastra, dan Pembelajarannya, Vol. 2 No 1, Tahun 2017, Hlm. 135150

Udiansyah. 2019. Milenial yang Berkarakter, Berkapasitas, dan Berdaya Saing. Disampaikan pada Seminar Peningkatan Pembinaan Bidang Kepemudaan Tahun 2019 di Aula LLDIKTI pada tanggal 26 Maret 2019.

Yuliani, Ina. 2019. Membangun Generasi Muda Berkualitas Melalui Pendidikan Karakter. Disampaikan pada Seminar Peningkatan Pembinaan Bidang Kepemudaan Tahun 2019 di Aula LLDIKTI pada tanggal 26 Maret 2019.

Sudrajat, Ajat. 2011. Mengapa Pendidikan Karakter? Jurnal Pendidikan Karakter, Th 1 No 1 (2011), Online, https://journal.uny.ac.id/index.php/jpka/issue/view/226, diakses pada tanggal 6 Maret 2019 
Kementerian Pendidikan Nasional. 2010. Pengembangan Budaya dan Karakter Bangsa. Jakarta: Kementerian Pendidikan Nasional.

Fajarini, Ulfah. 2014. Peranan Kearifan Lokal dalam Pendidikan Karakter. Jurnal sosio Didaktika: Social Science Education Journal Vol. I No. 2 (2014), Online, http://journal.uinjkt.ac.id/index.php/SOSIO-FITK/article/view/1225/1093, diakses pada tanggal 6 Maret 2019 